\title{
EFFECTS OF EPIDURAL ANAESTHESIA ON INTRAOPERATIVE CORE TEMPERATURE CHANGES IN COLORECTAL CANCER SURGERY
}

\author{
Kestutis Rimaitis*, Dainius Pavalkis**, and Juozas Pundzius** \\ * Department of Anaesthesia, Kaunas Medical University Hospital, Eiveniu-2, LT-50166, Kaunas, LITHUANIA; \\ e-mail: kestutis.rimaitis@kmuk.It \\ ** Clinic of Surgery, Kaunas Medical University Hospital, Eiveniu-2, LT-50166, Kaunas, LITHUANIA
}

\section{Communicated by Rafails Rozentāls}

The purpose of our study was to compare two different methods of anaesthesia in colorectal cancer surgery with respect to the level of intra-operative heat loss and to evaluate its influence on surgical outcome. One hundred patients scheduled to undergo elective colorectal cancer surgery were randomised to receive general anaesthesia (GEN group) or combined general and epidural anaesthesia (GEN + EA group), with 50 patients in each group. Induction and maintenance of general anaesthesia were performed the same way in both groups. Core temperature in lower 1/3 of oesophagus was measured every five minutes after induction of anaesthesia till the end of the surgery. All postoperative complications were registered. There were no significant differences between both groups in respect to patient characteristics and operations carried out. Core temperature decreased during surgery from $36.5 \pm 0.4{ }^{\circ} \mathrm{C}$ to $36.0 \pm 0.5{ }^{\circ} \mathrm{C}$ in the GEN group, compared to $36.3 \pm 0.4^{\circ} \mathrm{C}$ to $35.7 \pm 0.6^{\circ} \mathrm{C}$ in GEN + EA group. Moreover, heat loss in the GEN + EA group was significantly higher $(\mathrm{P}<0.05)$ than in the GEN group. Surgical complications occurred in four $(8 \%)$ patients in GEN group and eleven $(22 \%)$ in the GEN $+E A$ group $(\mathrm{P}=0.09)$. Our study showed that heating of intravenous infusion fluids is not enough to protect from heat loss intraoperatively. Oesophageal core temperature decreased in all patients, but heat loss was greater in the combined general and epidural anaesthesia group. It seems likely that mild hypothermia is an important risk factor in the development of postoperative surgical complications.

Key words: mild hypothermia, epidural anaesthesia, core temperature, colorectal surgery.

\section{INTRODUCTION}

There is an increasing number of patients suffering from malignant tumours all over the world. Colorectal cancer takes the third place among all cancer patients. Surgical operation is the only curative therapy of these patients. Modern surgical interventions became more extensive and associated with a major surgical trauma. Several studies have demonstrated a significant decrease in morbidity and mortality in high-risk surgical patients undergoing combined general and epidural anaesthesia followed by epidural analgesia postoperatively as compared to patients receiving high-dose narcotic anaesthesia and parenteral narcotic analgesia (Yeager et al., 1987; De Leon-Casasola et al., 1994; Liu et al., 1995; Handley et al., 1997; Buggy, 1999; Grass and Smith, 2000). It seems that anaesthetic and postoperative analgesic technique may be able to modify patients' outcome. Epidural anaesthesia (EA) has shown to have some beneficial effects intraoperatively: it attenuates stress response to surgical trauma by sympathetic blockade, stabilises haemodynamic parameters of the patient and significantly reduces blood loss (Liu et al., 1995). EA also im- proves splanchnic blood flow and oxygenation that result in the reduction of postoperative ileus (Scott et al., 1995; Block et al., 2003). Furthermore, EA reduces metabolic stress response and nitrogen loss (Hasoda et al., 1993; Carli et al., 1997). Combined general and epidural anaesthesia enables to reach an adequate anaesthesia level with reduced doses of anaesthetics and muscle relaxants (Handley et al., 1997). Moreover, epidural analgesia has demonstrated some beneficial effects for the treatment of postoperative pain as compared with systemic opioid analgesia (Kehlet et al., 1996; Block et al., 2003; Rimaitis et al., 2003) and resulted in the reduction of postoperative complications rate and shortened patients hospital stay (Yeager et al., 1987; De Leon-Casasola et al., 1994; Liu et al., 1995). However, there are several clinical investigations showing unfavourable effects of epidural anaesthesia on the thermoregulation and hypothermia development (Joris et al., 1994; Glosten et al., 1998). Controversies still exist about epidural analgesia effects on colorectal anastomosis and its influence on postoperative surgical complications rate (Ryan et al., 1992; Sala et al., 1997; Holte and Kehlet, 2001). Probably, the lack of standardisation has contributed to the continued con- 
fusion regarding the role of epidural anaesthesia on postoperative surgical outcome (Kehlet and Holte, 2001; Moraca et al., 2003). Moreover, pooling patients who underwent surgical procedures in different areas of the body and anaesthetised by different anaesthetic technique in one single study makes the comparison of data difficult (Kehlet and Holte, 2001). There are few clinical studies evaluating in complex the influence of choice of anaesthesia and analgesia on patients' outcome after cancer surgery (De LeonCasasola et al., 1994; Handley et al., 1997; Rimaitis et al., 2003).

The aim of our study was to compare two different methods of anaesthesia in respect to hypothermia development intraoperatively and postoperative complications rate using two standardised anaesthesia techniques in one field of major abdominal surgery-colorectal cancer surgery.

\section{MATERIALS AND METHODS}

This study was conducted during a 24-month period and designed as a prospective, randomised clinical investigation. The study protocol was approved by the local Ethics Committee and informed written consent was obtained from each patient. All patients who were scheduled to undergo elective colorectal cancer resection and whose physical statement according to ASA (American Society of Anaesthesiologists) was classified to class I-III were included in the study ( $n=100)$. Patients, who refused to take part in this clinical study $(\mathrm{n}=36)$, with contraindications to epidural anaesthesia $(\mathrm{n}=26)$, who underwent urgent surgery $(\mathrm{n}=$ 54), as well as those with ASA physical status exceeding III $(n=23)$ and with limited ability to cooperate $(n=17)$ were excluded.

All patients randomly were allocated into two groups: combined general and epidural anaesthesia followed by epidural analgesia (GEN + EA group) and balanced general anaesthesia followed by systemic opioid analgesia (GEN group). The same anaesthesiologist anaesthetised all patients and the same team of colorectal surgeons performed all operations.

Approximately $1 \mathrm{~h}$ before arrival to the operating theatre, all patients were pre-medicated with oral diazepam $10 \mathrm{mg}$ and IV infusion of $10 \mathrm{ml} / \mathrm{kg}$ Ringer's lactate solution was given preoperatively. For patients in the GEN + EA group, following placement of routine monitoring in the operating room, an epidural catheter was placed in one of $\mathrm{T}_{10}-\mathrm{L}_{1}$ interspaces, with the tip of the catheter advanced $4-5 \mathrm{~cm}$ into the epidural space. All catheters were tested for accidental intravascular or subarachnoid placement with $3 \mathrm{ml}$ of $2 \%$ lidocaine and epinephrine $15 \mu \mathrm{g}$. Bupivacaine 2.5 $\mathrm{mg} / \mathrm{ml}$ with fentanyl $10 \mu \mathrm{g} / \mathrm{ml}$ was then injected through the epidural catheter in $5 \mathrm{ml}$ increments till epidural block up to $\mathrm{T}_{4}$ was established.

General anaesthesia was induced the same way in both groups: with propofol $1.5-2.5 \mathrm{mg} / \mathrm{kg}$ and fentanyl $2-3$ $\mu \mathrm{g} / \mathrm{kg}$, muscle relaxation was accomplished using pipecuronium $50-60 \mu \mathrm{g} / \mathrm{kg}$, and the trachea was intubated. Immediately after tracheal intubation an oesophageal thermometer was placed in the lower 1/3 of oesophagus. Anaesthesia was maintained with IV propofol infusion at the rate of 3-5 $\mathrm{mg} / \mathrm{kg} / \mathrm{h}$. Fentanyl infusion at the rate of $3-5 \mu \mathrm{g} / \mathrm{kg} / \mathrm{h}$ in the GEN group and epidural infusion 3-6 $\mathrm{ml} / \mathrm{h}$ of bupivacaine $2.5 \mathrm{mg} / \mathrm{ml}$ with fentanyl $10 \mu \mathrm{g} / \mathrm{ml}$ in the GEN + EA group was used to maintain analgesia until the patient was transferred from the operating room. Ventilation was maintained with oxygen in air mixture $\left(\mathrm{FiO}_{2}\right.$ of $\left.33 \%\right)$. Any volatile anaesthetic agents were used in both groups. Inhaled gases were not heated or humidified.

Permanent monitoring of electrocardiogram (ECG), heart rate, non-invasive blood pressure (NIBP), $\mathrm{SaO}_{2}$, capnography, spirometry and ventilation gases analysis by DatexEngstrom monitoring system "Cardiocap II CH-2" and "Capnomac Ultima" (Finland) was established during the operation. Core temperature in oesophagus was measured every five minutes after induction of anaesthesia till the end of the surgery, registering the stage of operation. Temperature in the operating theatre was kept at $22 \pm 2{ }^{\circ} \mathrm{C}$ level in all cases. Intravenous infusion fluids were heated in a thermostatic cupboard to $37{ }^{\circ} \mathrm{C}$ and their temperature was the same in both groups. All postoperative complications and patient hospital stay were accurately recorded.

Postoperative pain-relief treatment was started within 15 min after patient admission to the post-anaesthesia care unit. All patients in the GEN group received IM pethidine $0.5-1.0 \mathrm{mg} / \mathrm{kg}$ every four hours and all patients in the GEN + EA group were given continuous infusion of $1.0 \mathrm{mg} / \mathrm{ml}$ bupivacaine with $5 \mu \mathrm{g} / \mathrm{ml}$ fentanyl into an epidural catheter by syringe driver at the rate of $3-6 \mathrm{ml} / \mathrm{h}$ for the first three days postoperatively.

Statistical analysis was performed using "Statistica 6" software for Windows' 98 (StatSoft Inc.Tulsa, USA). Parametric data (age, weight, duration of surgery, core, blood loss, infusion therapy and diuresis) were compared using Student's t-test for independent samples. Core temperature changes intraoperatively were compared using two-factorial ANOVA for multiple repeated measurements. Nonparametric data such as physical statement according to ASA were analysed using the Mann-Whitney U test. The Chi-square and two tailed Fisher's exact test for sex and complications rate analysis was used. All data are presented as mean \pm standard deviation $(\mathrm{SD}) . P<0.05$ was considered as statistically significant.

\section{RESULTS}

The patient characteristics are given in Table 1 . There were no statistically significant differences between the two groups in respect to sex, age, body weight and height and ASA physical statement. 
DEMOGRAPHIC PATIENT DATA IN STUDY GROUPS

\begin{tabular}{lcc}
\hline \multicolumn{1}{c}{ Demographic criteria } & $\begin{array}{c}\text { GEN group, } \\
\mathrm{n}=50\end{array}$ & $\begin{array}{c}\text { GEN + EA group, } \\
\mathrm{n}=50\end{array}$ \\
\hline Female & $26(52 \%)$ & $25(50 \%)$ \\
Male & $24(48 \%)$ & $25(50 \%)$ \\
Age (years) & $67 \pm 11$ & $65 \pm 13$ \\
Weight (kg) & $70 \pm 11$ & $74 \pm 13$ \\
Height $(\mathrm{cm})$ & $167 \pm 8$ & $169 \pm 9$ \\
ASA - I & $6(12 \%)$ & $5(10 \%)$ \\
ASA - II & $32(64 \%)$ & $32(64 \%)$ \\
ASA - III & $12(24 \%)$ & $13(26 \%)$
\end{tabular}

GEN group: group of general anaesthesia alone. GEN + EA group: group of combined general and epidural anaesthesia. Gender and ASA physical statement data presented as n (\%). Age, weight and height presented as mean \pm standard deviation. $P$ value was $>0.05$ in all categories of demographic criteria.

Colorectal carcinoma was complicated by partial ileus, anaemia, metastatic carcinoma or both in $28(56 \%)$ patients of the GEN group and in $25(50 \%)$ of the GEN + EA group $(P>0.5)$. Surgical operations and duration of surgery are shown in Table 2.

There were no significant differences between the two groups in respect to surgical procedure or duration of surgery.

Intra-operative IV infusion therapy was similar in both groups: $3000 \mathrm{ml} \pm 1000 \mathrm{ml}$ in the GEN group compared with $3100 \pm 700 \mathrm{ml}$ in the GEN + EA group $(P>0.05)$. Blood loss was $347 \pm 463 \mathrm{ml}$ in the GEN group, compared with $245 \pm 238 \mathrm{ml}$ in the GEN + EA group (without statistical significance, $P>0.05)$. Urine output during surgery also was similar in both groups $(P>0.05): 317 \pm 133 \mathrm{ml}$ and $354 \pm 198 \mathrm{ml}$, respectively.

In the morning before surgery, axillar temperature was measured in all study patients. There was no difference between the study groups in respect to body temperature: 36.6
TYPE AND DURATION OF SURGICAL PROCEDURES IN STUDY GROUPS

\begin{tabular}{lcccc}
\hline \multicolumn{1}{c|}{ Surgery } & GEN group & $\begin{array}{c}\text { GEN+EA } \\
\text { group }\end{array}$ & P \\
\hline Anterior rectal resection & $20(40 \%)$ & $21(42 \%)$ & 0,84 \\
Total proctectomy & $4(8 \%)$ & $6(12 \%)$ & 0,51 \\
Abdomino-perineal resection & $4(8 \%)$ & $6(12 \%)$ & 0,51 \\
Sigmoid colectomy & $3(6 \%)$ & $3(6 \%)$ & 1,0 \\
Left hemicolectomy & $4(8 \%)$ & $5(10 \%)$ & 0,73 \\
Right hemicolectomy & $9(18 \%)$ & $5(10 \%)$ & 0,25 \\
Extended operations* & $6(12 \%)$ & $4(8 \%)$ & 0,51 \\
Duration of surgery (min) & $141 \pm 45$ & $144 \pm 38$ & 0,72
\end{tabular}

GEN group: group of general anaesthesia alone. GEN + EA group: group of combined general and epidural anaesthesia. Surgical procedures presented as n (\%). Duration of surgery presented as mean \pm standard deviation. $P$ value was $>0.05$ in all categories of demographic criteria

* Extended operations-large bowel resections with simultaneously performed gynecological or other operations caused by invasion of malignant process or another disease.

$\pm 0.4{ }^{\circ} \mathrm{C}$ in the GEN group compared with $36.5 \pm 0.5{ }^{\circ} \mathrm{C}$ in the GEN + EA group $(P>0.05)$. After general anaesthesia induction, when an oesophageal thermometer was introduced, core temperature in the GEN group was $36.51 \pm 0.39$ ${ }^{\circ} \mathrm{C}$ as compared with $36.30 \pm 0.39{ }^{\circ} \mathrm{C}$ in the GEN + EA group. This difference was statistically significant $(P<$ 0.05 ) and can be explained by sympathetic blockade and peripheral vasodilatation after epidural block establishment in the GEN + EA group. Till the end of surgery, core temperature decreased in both groups: to $36.01 \pm 0.54{ }^{\circ} \mathrm{C}$ in the GEN group and to $35.69 \pm 0.64{ }^{\circ} \mathrm{C}$ in the GEN + EA group. Core temperature during all surgery was significantly lower in the GEN + EA group than in the GEN group $(P<0.05)$. Core temperature changes in study groups during surgery are shown in Figure 1.

As shown in Figure 1, the patients of the GEN + EA group became more hypothermic during all stages of surgery com-

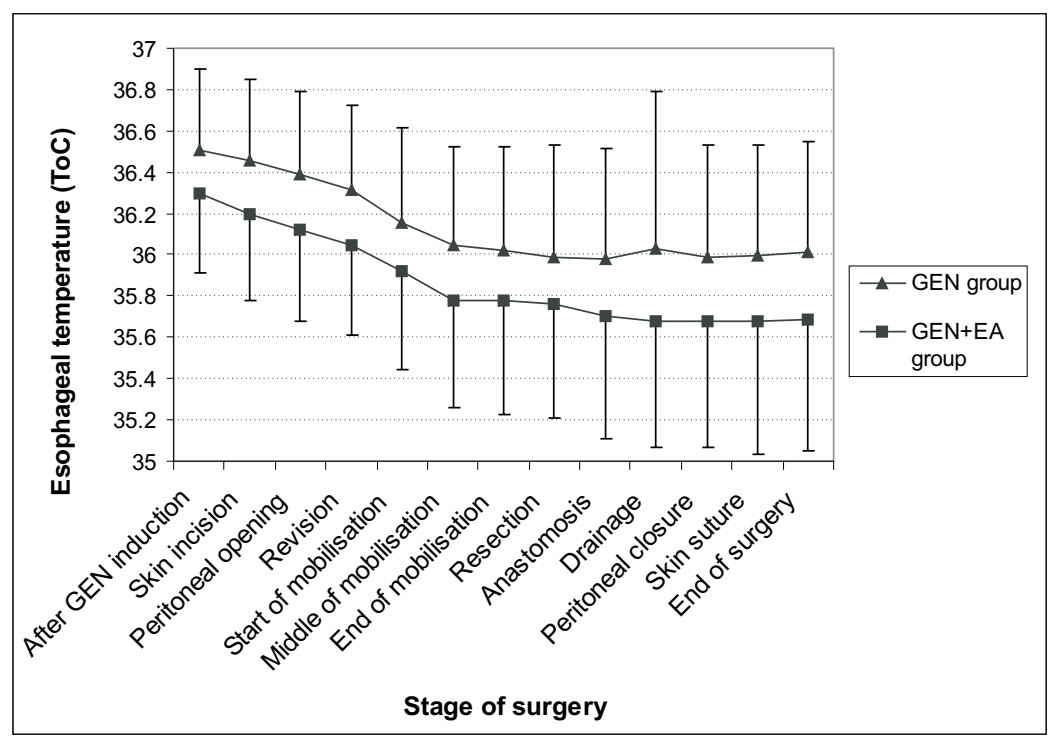

Fig. 1. Comparison of intra-operative core temperature changes between the study groups.

GEN group: group of general anaesthesia alone. GEN + EA group: group of combined general and epidural anaesthesia. Data are presented as mean $+\mathrm{SD}$ in the GA group and as mean - SD in the GA + EA group. Mean core temperature in the GEN + EA group decreased $0.3{ }^{\circ} \mathrm{C}$ more than in the GEN group during the period of surgery $(95 \%$ confidence interval for difference: $0.1-0.46{ }^{\circ} \mathrm{C}$ ) 
pared with patients in the GEN group, with statistical significance of $(P<0.05)$ except at the beginning of large bowel mobilisation stage, when core temperature was similar in both groups $(P>0.05)$

Postoperative course was complicated in nine (18\%) patients in the GEN group compared with 12 (24\%) patients in the GEN + EA group. There were no significant differences between groups in respect to total postoperative complications rate $(P>0.05)$. However, surgical complications developed in four $(8 \%)$ patients in the GEN group compared with $11(22 \%)$ patients in the GEN + EA group $(P=0.09)$. Postoperative complications in the study groups are presented in Table 3.

Table 3

POSTOPERATIVE COMPLICATIONS IN STUDY GROUPS

\begin{tabular}{lcc}
\hline Surgical complication & GEN group N (\%) & GEN + EA group N (\%) \\
\hline Wound infection & $3(6 \%)$ & $5(10 \%)$ \\
Intraabdominal abscess & $1(2 \%)$ & $3(6 \%)$ \\
Anastomotic leak & - & $3(6 \%)$ \\
Total & $4(8 \%)$ & $11(22 \%)$ \\
\hline Other complications & GEN group N $(\%)$ & GEN + EA group N (\%) \\
Chest infection & $2(4 \%)$ & $1(2 \%)^{*}$ \\
Cardiac arrhythmias & $2(4 \%)$ & - \\
Pulmonary embolism & $1(2 \%) \dagger$ & - \\
Acute renal failure & - & $1(2 \%)^{*}$ \\
Urinary tract infection & - & $1(2 \%)$ \\
Total & $5(10 \%)$ & $3(6 \%)$
\end{tabular}

GEN group: group of general anaesthesia alone. GEN + EA group: group of combined general and epidural anaesthesia.

* Subsequent complications to the same patients with intraabdominal abscess.

Patient died from massive pulmonary thrombi embolism.

Patients were discharged from hospital after $10 \pm 4$ days postoperatively in the GEN group compared to $11 \pm 5$ days in the GEN + EA group and there were no significant differences between two groups in respect to postoperative hospital stay $(P>0.05)$.

\section{DISCUSSION}

Results of our study showed that both methods of anaesthesia caused a decrease in core temperature during surgery, while the level of heat loss was greater using combined general and epidural anaesthesia as compared with general anaesthesia alone. Hypothermia during surgery can cause some adverse effects such as prolonged action of anaesthetics, occurrence of coagulopathy (Valeri et al., 1987). Moreover, hypothermia suppresses immune defence mechanisms and increases the possibility of wound infection (Kurz et al., 1996; Beilin et al., 1998). Postoperative shivering also is more frequent in hypothermic patients and can cause unex- pected life-threatening myocardial ischemia (Camus et al., 1996; Kim et al., 1998). Development of hypothermia depends on extensiveness of surgery, type of anaesthesia and environment conditions. Intraoperative hypothermia during general anaesthesia is caused by impaired central thermoregulation: core-to-peripheral redistribution of body heat and by heat loss exceeding metabolic heat production (Sessler, 2000) and is suppressed by thermoregulatory peripheral vasoconstriction. Epidural anaesthesia produces peripheral vasodilatation especially in the lower extremities and causes more rapid body heat loss (Sessler, 2008). This is the reason why combined general and epidural anaesthesia causes more elevated hypothermia during major abdominal surgery than general anaesthesia alone (Siniscalchi et al., 2003; Danelli et al., 2004).

Most of the authors mentioned in the references show that a combination of epidural anaesthesia with general anaesthesia has some beneficial effects intraoperatively: it improves haemodynamic stability of the patient, reduces blood loss, allows to reduce doses of anaesthetic drugs and muscle relaxants and improves recovery characteristics (Yeager et al., 1987; De Leon- Casasola et al., 1994; Liu et al., 1995; Handley et al., 1997; Buggy and Smith, 1999; Grass, 2000). Postoperative continuous epidural analgesia demonstrates better pain relief and self-satisfaction of the patients as compared with systemic opioid analgesia (Rimaitis et al., 2003; Flisberg et al., 2003). Moreover, postoperative continuous epidural analgesia allows early physical activity of the patients and speeds recovery of gut function (De LeonCasasola et al., 1994; Liu et al., 1995; Handley et al., 1997; Buggy and Smith, 1999; Grass, 2000). These effects reduce the postoperative complication rate and shorten hospital stay after major abdominal surgery. However, our study showed similar total postoperative complication rate and hospital stay in both groups. Surprisingly, surgical complication developed even more often in the GEN + EA group-11 $(22 \%)$ patients as compared with $4(8 \%)$ patients in the GEN group. These differences lacked statistical significance $(P>0.05)$, but were nevertheless clinically important. In our opinion, mild hypothermia during surgery plays an important role in the development of postoperative surgical complications.

In conclusion, we found heating of IV infusion solutions insufficient to prevent heat loss during major abdominal surgery. Oesophageal core temperature decreased in all anaesthetised patients, but epidural anaesthesia caused greater heat loss when combined with general anaesthesia to compare with general anaesthesia alone. It seems likely that mild hypothermia is an important risk factor in postoperative surgical complications development after colorectal cancer surgery. Introduction of active forced air heating devices into routine clinical practice will enable us to keep normothermia in patients during surgery. Expanded further clinical studies are required to determine the influence of anaesthesia methods on surgical outcome in colorectal cancer surgery. 


\section{REFERENCES}

Beilin, B., Shavit, Y., Razumovsky, J., Wolloch, Y., Zeidel, A., Bessler, H. (1998). Effects of mild perioperative hypothermia on cellular immune responses. Anesthesiology, 89, 1133-1140.

Block, B.M., Liu, S.S., Rowlingson, A.J., Cowan, A.R., Cowan, J.A. Jr., Wu, C.L. (2003). Efficacy of postoperative epidural analgesia. A meta-analysis. J.A.M.A., 290(18), 2455-2463.

Bredtman, R.D., Herden, H.N., Teichmann, W., Moecke, H.P., Kniesel, B., Baetgen, R., Tecklenburg, A. (1990) Epidural analgesia in colonic surgery: Results of randomized prospective study. Brit. J. Surg., 77(6), 638-642.

Buggy, D.J., Smith, G. (1999). Epidural anaesthesia and analgesia: better outcome after major surgery? BMJ, 319(28), 530-531.

Camus, Y., Delva, E., Cohen, S., Lienhart, A. (1996). The effects of warming intravenous fluids on intraoperative hypothermia and postoperative shivering during prolonged abdominal surgery. Acta Anaesth. Scand., 40, $779-782$

Carli, F., Phil, M., Halliday, D. (1997). Continuous epidural blockade arrests the postoperative decrease in muscle protein fractional synthetic rate in surgical patients. Anesthesiology, 86, 1033-1040.

Crowley, L.J., Buggy, D.J. (2008). Shivering and neuraxial anesthesia. Reg. Anesth. Pain Med., 33(3), 241-252.

Danelli, G., Berti, M., Perotti, V., Albertin, A., Baccari, P., Deni, F., Fanelli, G., Casati, A. (2004). Temperature control and recovery of bowel function after laparoscopic or laparotomic colorectal surgery in patients receiving combined epidural/general anesthesia and postoperative epidural analgesia. Anesth. Analg., 95, 467-471.

De Leon-Casasola, O.A., Parker, B.M., Lema, M.J., Groth, R.I., OrsiniFuentes, J. (1994). Epidural analgesia versus intravenous patient-controlled analgesia. Differences in the postoperative course of cancer patients. Reg. Anesth., 19(5), 307-315.

Flisberg, P., Rudin, A., Linner, R., Lundberg, C.J.F. (2003). Pain relief and safety after major surgery. A prospective study of epidural and intravenous analgesia in 2696 patients. Acta Anesthesiol. Scand., 47, 457-465.

Glosten, B., Savage, M., Rooke, G.A., Brengelmann, G.L. (1998). Epidural anesthesia and thermoregulatory responses to hyperthermia-preliminary observations in volunteer subjects. Acta Anaesthesiol. Scand., 42, $442-446$

Grass, J.A. (2000). The role of epidural anesthesia and analgesia in postoperative outcome. Anesthesiol. Clin. North America, 18(2), 407-428.

Handley, G.H., Silbert, B.S, Mooney, P.H., Schweitzer, S.A., Allen, N.B. (1997). Combined general and epidural anesthesia versus general anesthesia for major abdominal surgery: Postanesthesia recovery characteristics. Reg. Anesth., 22(5), 435-441.

Hasoda, R., Hattori, M., Shimada,Y. (1993). Favorable effects of epidural analgesia on hemodynamics, oxygenation and metabolic variables in the immediate post-anesthetic period. Acta Anaesth. Scand., 37, 469-474.
Holte, K., Kehlet, H. (2001). Epidural analgesia and risk of anastomotic leakage. Reg. Anesth. Pain Med., 26(2), 111-117.

Joris, J., Ozaki, M., Sessler, D.I., Hardy, A.F., Lamy, M., McGuire, J., Blanchard, D., Schroeder, M., Moayeri, A. (1994). Epidural anesthesia impairs both central and peripheral thermoregulatory control during general anesthesia. Anesthesiology, 80, 268-277.

Kehlet, H., Holte, K. (2001). Effect of postoperative analgesia on surgical outcome. Brit. J. Anaesth., 87(1), 62?72.

Kim, J.S., Ikeda, T., Sessler, D.I., Turakhia, M., Jeffrey, R. (1998). Epidural anesthesia reduces the pain and maximum intensity of shivering. Anesthesiology, 88, 851-857.

Kurz, A., Sessler, D.I., Lenhardt, R. (1996). Perioperative normothermia to reduce the incidence of surgical-wound infection and shorten hospitalization. New Eng. J. Med., 334(19), 1209-1215.

Liu, S., Carpenter, R.L., Nea, J.M. (1995). Epidural anesthesia and analgesia. Their role in postoperative outcome. Rev. Anesthesiology, 82, 1474-1506.

Moraca, R.J., Sheldon,D.G., Thirlby, R.C. (2003). The role of epidural anesthesia and analgesia in surgical practice. Ann. Surg., 238(5), 663-673.

Rimaitis, K., Marchertiene, I., Pavalkis, D. (2003). Comparison of two different methods of analgesia. Postoperative course after colorectal cancer surgery. Medicina, 39(2), 129-137.

Ryan, P., Schweitzer, S.A., Woods, R.J. (1992). Effect of epidural and general anaesthesia compared with general anaesthesia alone in large bowel anastomoses. Eur. J. Surg., 158, 45-49.

Sala, C., Garcķa-Granero, E., Molina, M.J., Garcķa, J.V., Lledo, S. (1997). Effect of epidural anaesthesia on colorectal anastomosis. A tonometric assessment. Dis. Colon Rectum, 40(8), 958-961.

Scott, N.B., James, K., Murphy, M., Kehlet, H. (1996). Continuous thoracic epidural analgesia versus combined spinal/thoracic epidural analgesia on pain, pulmonary function and the metabolic response following colonic resection. Acta Anaesth. Scand., 40, 691-696.

Scott, D.A., Beilby, D.S.N., McClymont, C. (1995). Postoperative analgesia using epidural infusions of fentanyl with bupivacaine. A prospective analysis of 1014 patients. Anesthesiology, 83, 727-737.

Sessler, D.I. (2000). Perioperative heat balance. Anesthesiology, 92(2), 578-596.

Sessler, D.I. (2008). Temperature monitoring and perioperative thermoregulation. Anesthesiology, 109(2), 318-338.

Siniscalchi, A., Begliomini, B., Matteo, G., De Pietri, L., Pasetto, A. (2003. Intraoperative effects of combined versus general anesthesia during major liver surgery. Minerva Anestesiol., 69(12), 885-895 (in Italian).

Valeri, C.R., Feingold, H., Cassidy, G., Ragno, G., Khuri, S., Altschule, M.D. (1987). Hypothermia-induced reversible platelet dysfunction. Ann. Surg., 205, 175-181.

Yeager, M., Glass, D.D., Neff, R.K., Brinck-Johnson, T. (1987). Epidural anesthesia and analgesia in high risk surgical patients. Anesthesiology, 66, 729-736.

Received 12 August 2008

\section{EPIDURĀLĀS ANESTĒZIJAS IETEKME UZ KERMEN̦A SERDES TEMPERATŪRU KOLOREKTĀLO AUDZĒJU OPERĀCIJAS LAIKĀ}

Pētījuma mērķis bija salīdzināt divu atšķirīgu anestēzijas metožu ietekmi uz ķermeņa siltuma zudumu un k̦irurǵisko iznākumu kolorektālo audzēju operācijas laikā. 50 randomizētiem pacientiem plānveida operācija tika veikta vispārējā anestēzijā un 50 pacientiem kombinētā vispārējā un epidurālā anestēzijā. Ķermeņa serdes temperatūra mērīta ik pēc piecām minūtēm pēc ievadanestēzijas līdz operācijas beigām barības vada apakšējā trešdạ̦ā. Veicot tikai vispārējo anestēziju, serdes temperatūra operācijas laikā samazinājās no $36,5 \pm 0,4{ }^{\circ} \mathrm{C}$ uz $36,0 \pm$ $0,5{ }^{\circ} \mathrm{C}$, bet, realizējot kombinēto anestēziju, - no $36,3 \pm 0,4{ }^{\circ} \mathrm{C}$ uz $35,7 \pm 0,6{ }^{\circ} \mathrm{C}(P<0,05)$. Tâtad pēdējā pacientu grupā siltuma zudums bija izteiktāks $(P<0,05)$. Kirurğiskās komplikācijas vispārējās anestēzijas grupā novērotas četriem $(8 \%)$ pacientiem, bet kombinētās anestēzijas grupā - vienpadsmit $(22 \%)$ pacientiem $(P>0,05)$. Pētījums liecina, ka pasīva sildīšana ar sasildītiem intravenoziem infūzu šḳīdumiem ir nepietiekama, lai pasargātu ḳermeni no atdzišanas operācijas laikā. Mērena hipotermija ir būtisks postoperatīvo kirurğisko komplikāciju riska faktors. 